\title{
Post-Grenvillian tectonomagmatic evolution of the southwestern Laurentian front
}

Munazzam Ali Mahar, Anthony Alvarez, Jason Ricketts, Philip Goodell University of Texas at El Paso 


\section{Methods}

Zircon U-Pb dating of West Texas granites and associated Basalt dikes.

Zircon Hf isotopes composition

Whole-rock geochemistry

Integrating geochronological and geochemical data with spatially and temporally related magmatic rocks. 


\section{Orientation of Laurentia with respect to western and southern}

continents at $\sim 1.1 \mathrm{Ga}$

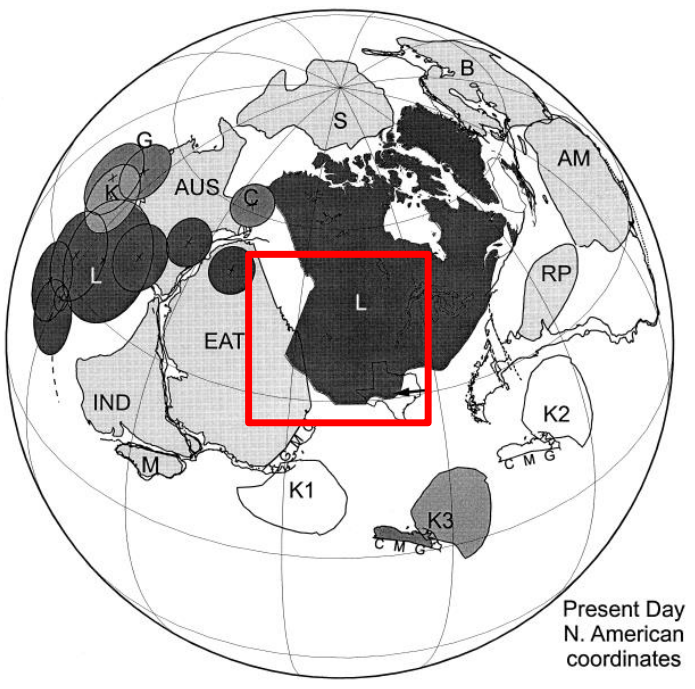

Dalziel et al., 2000

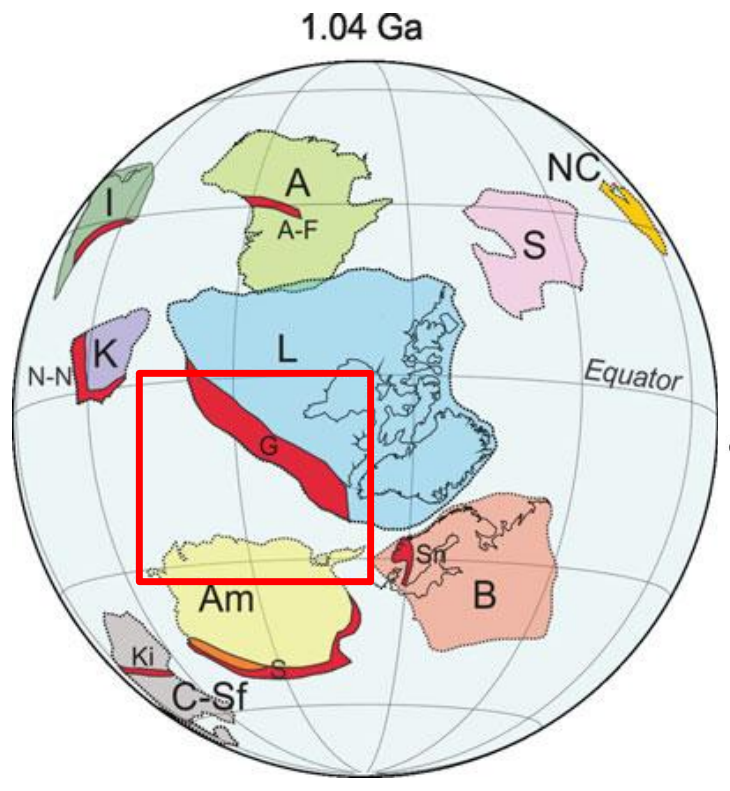

Mertanen and Pesonen, 2012
13

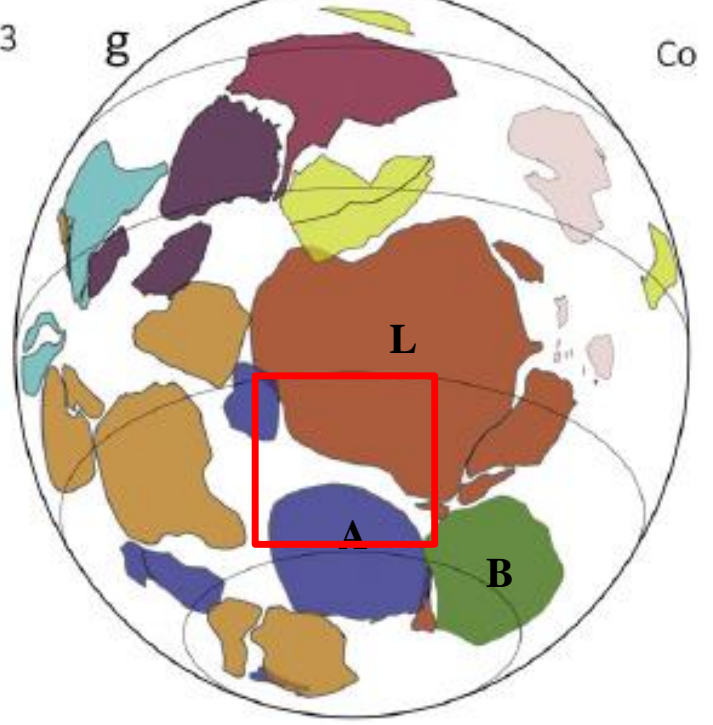

Li et al., 2008

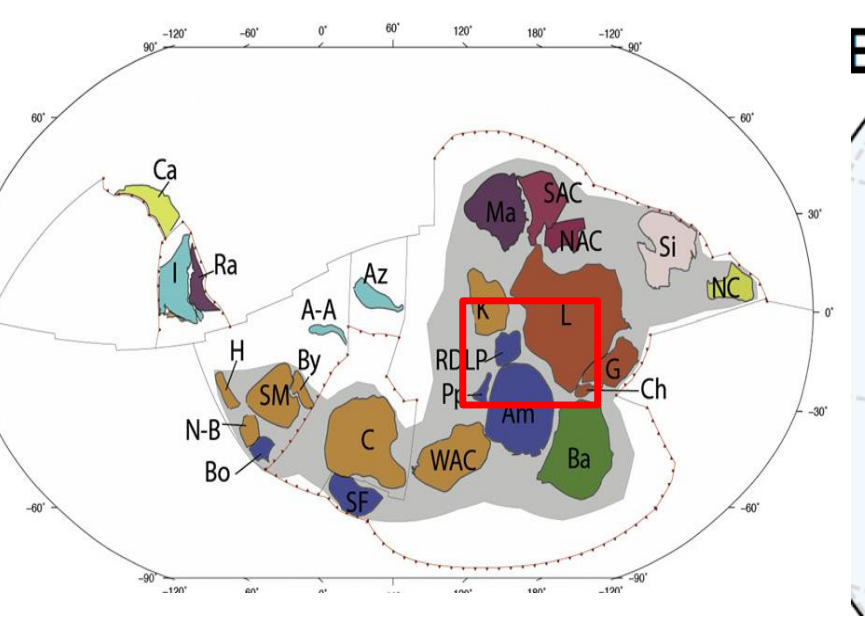

Merdit et al., 2017

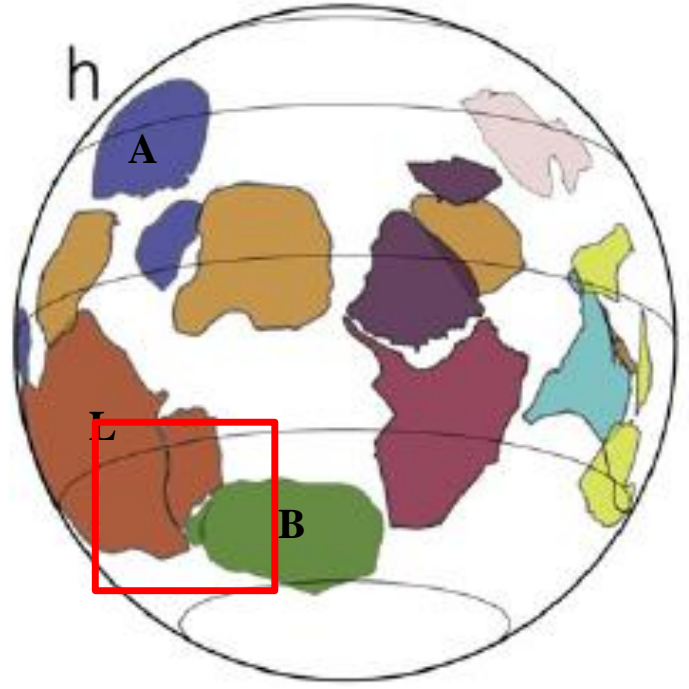

Evan, 2009

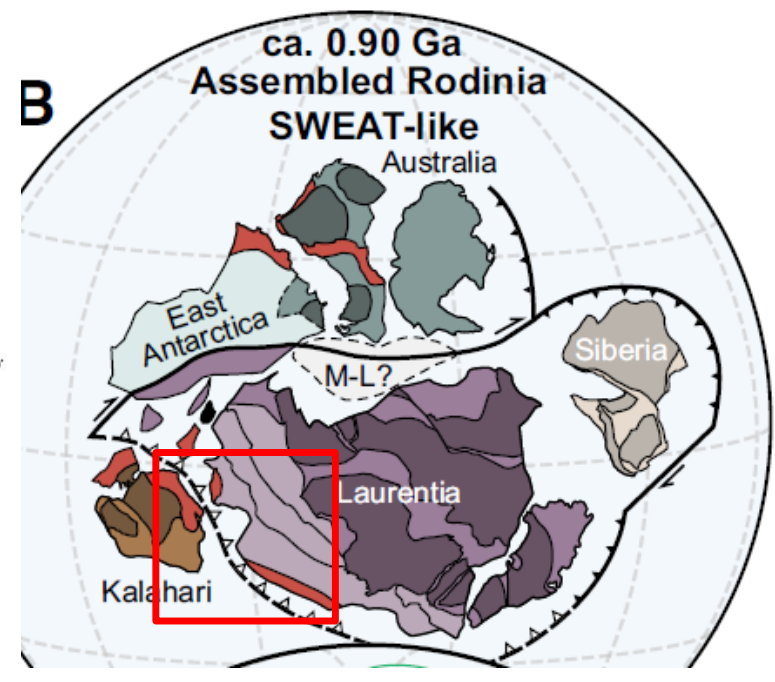

Mulder et al., 2018 


\section{Southwestern and South eastern Laurentia and Grenvillian orogeny (1.3-1.1Ga)}
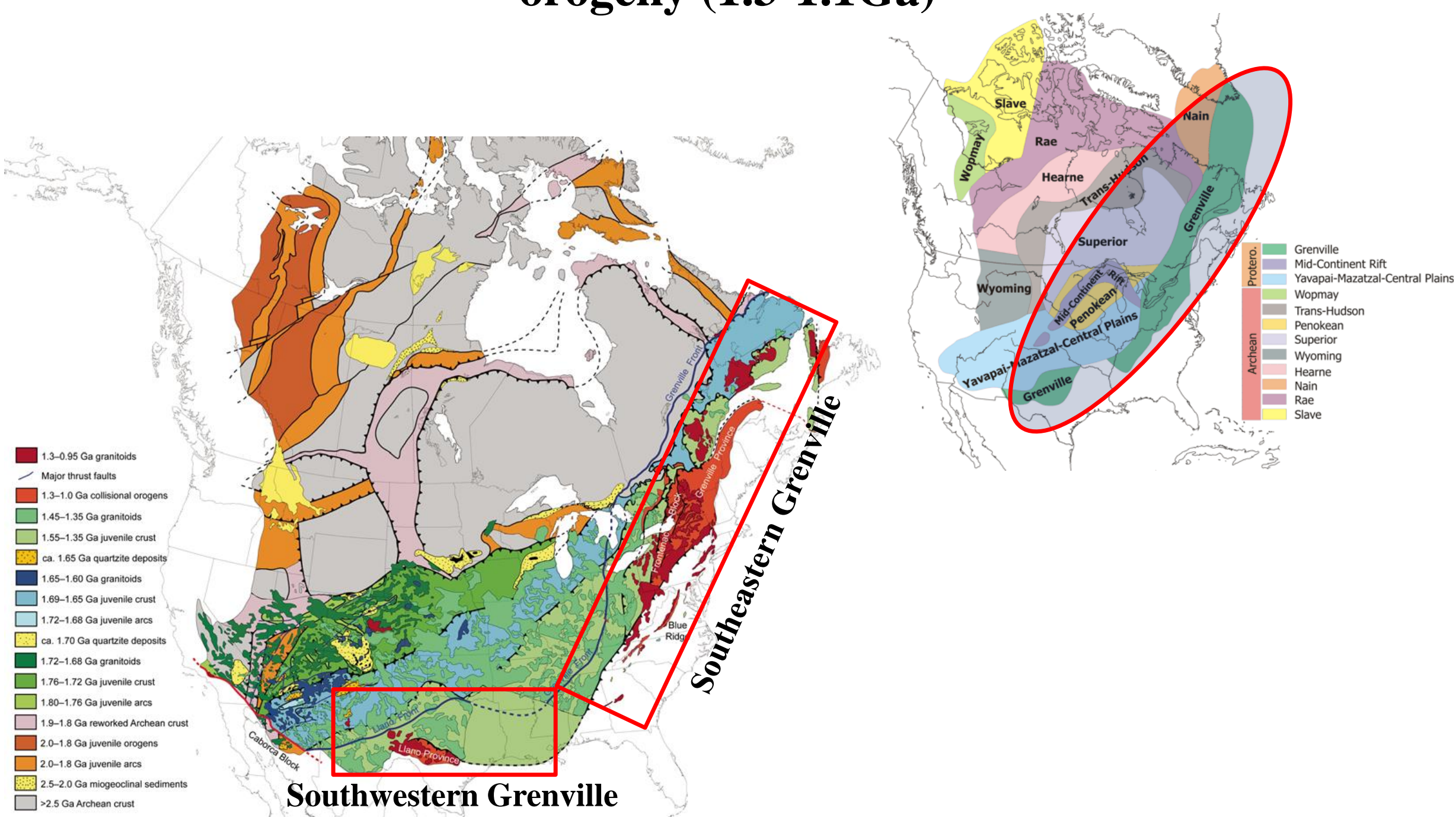


\section{Lithotectonic units and Pre Neoproterozoic Geology of Southwestern Laurentia}

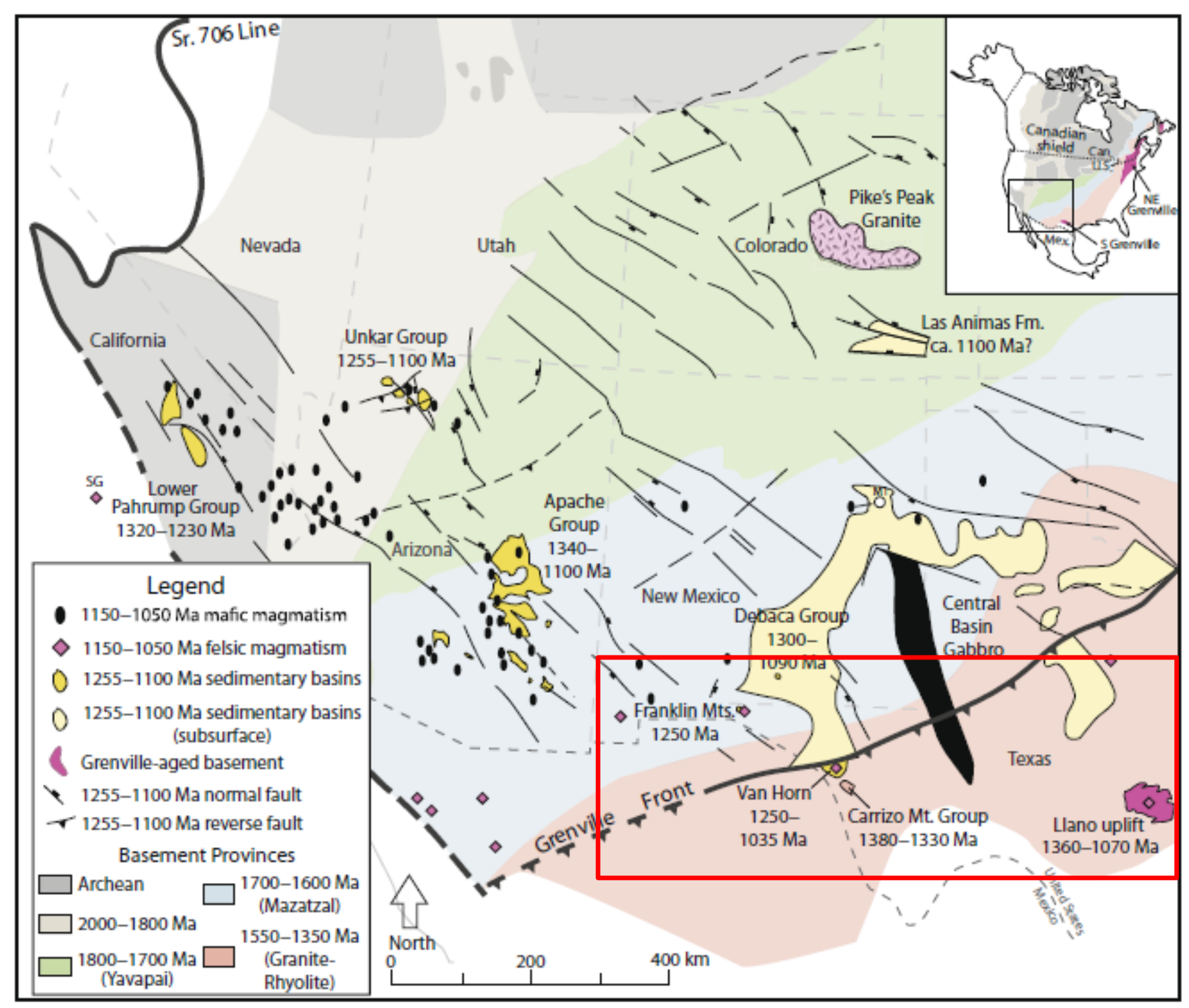

Mulder et al., 2017 


\subsection{Ga magmatism in southwestern Laurentia and Franklin Mountain}

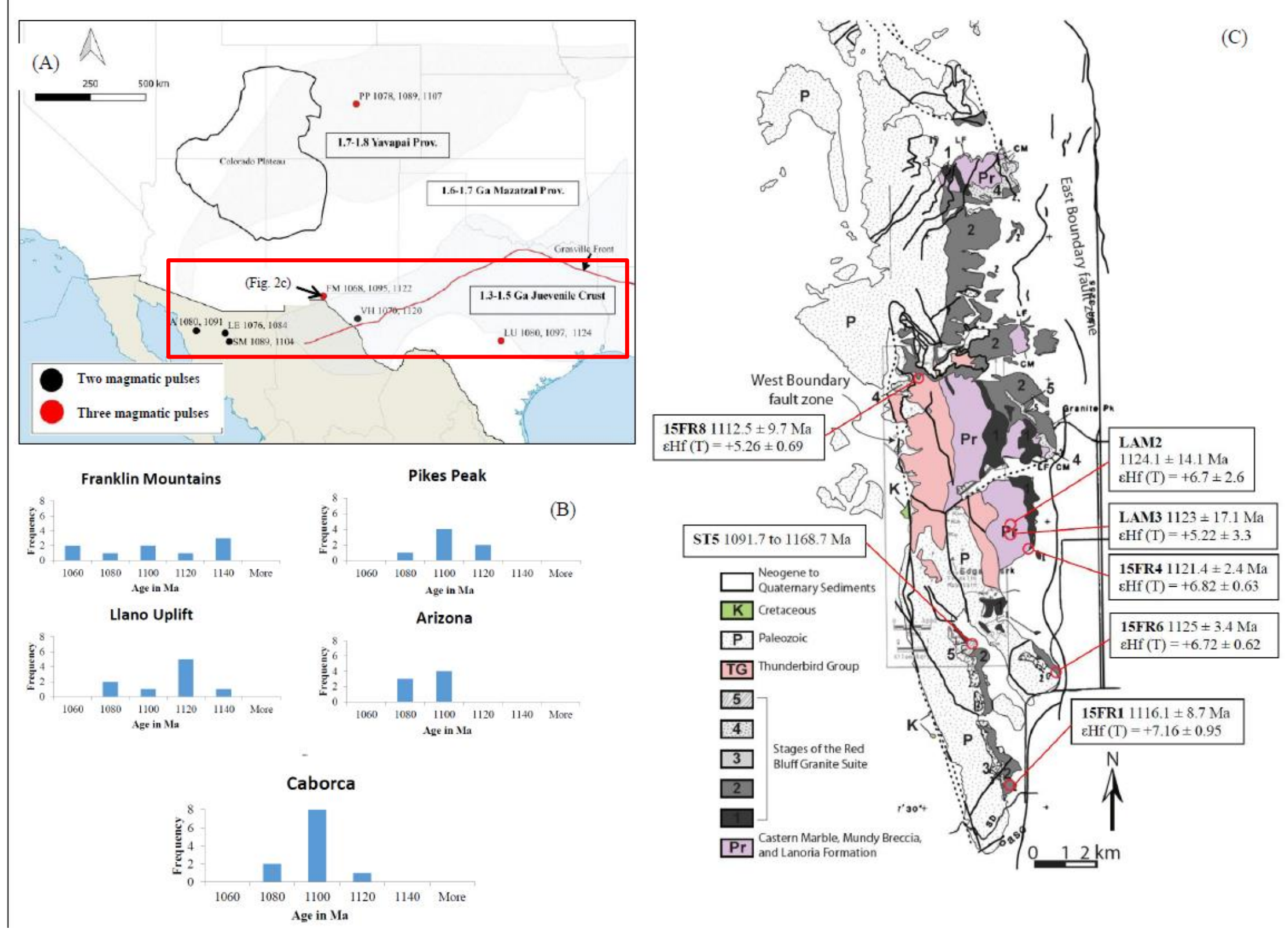




\section{Red Bluff granite and diabase dikes}

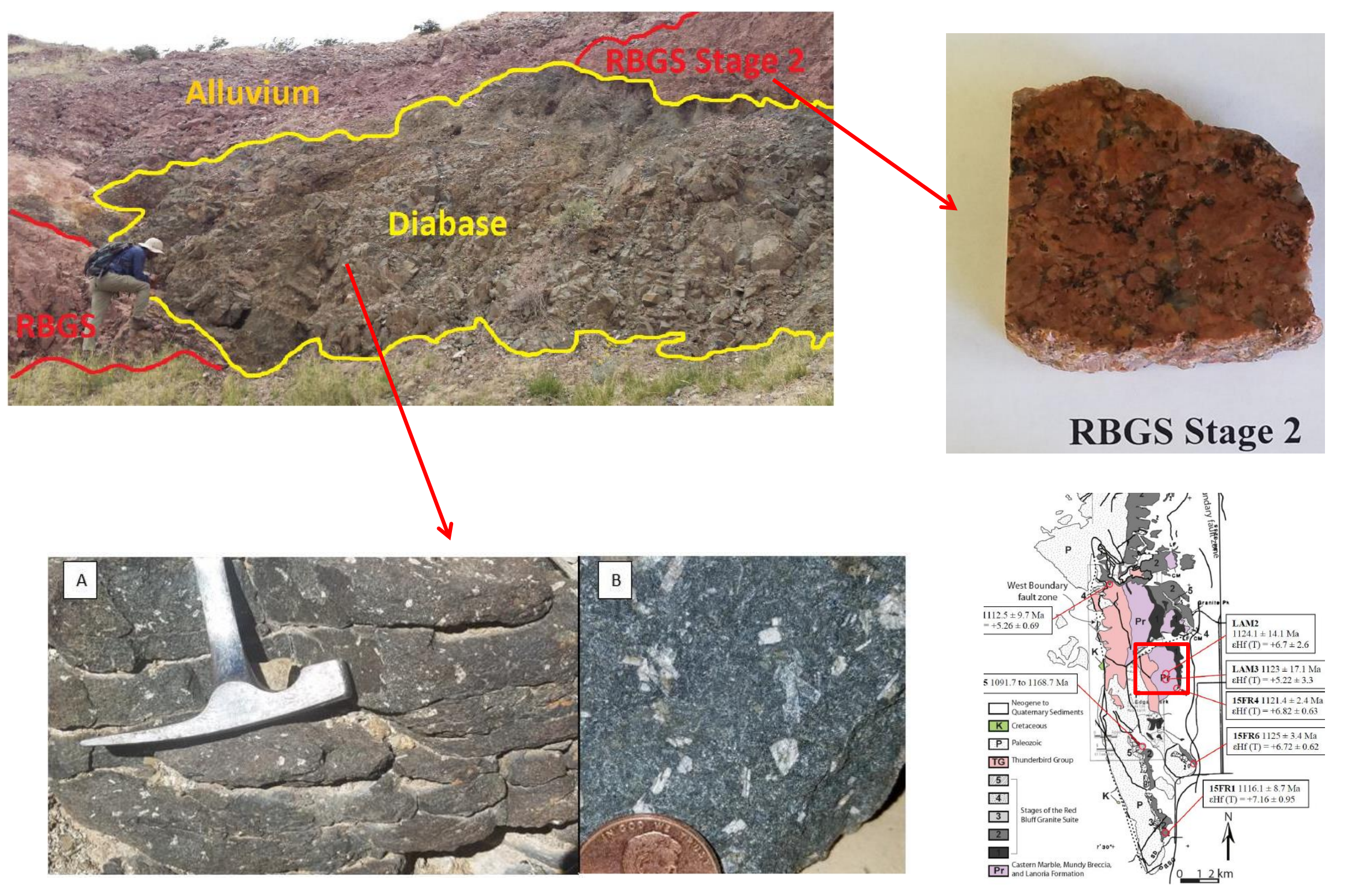




\section{Geochemistry Red Bluff granite and mafic dikes}

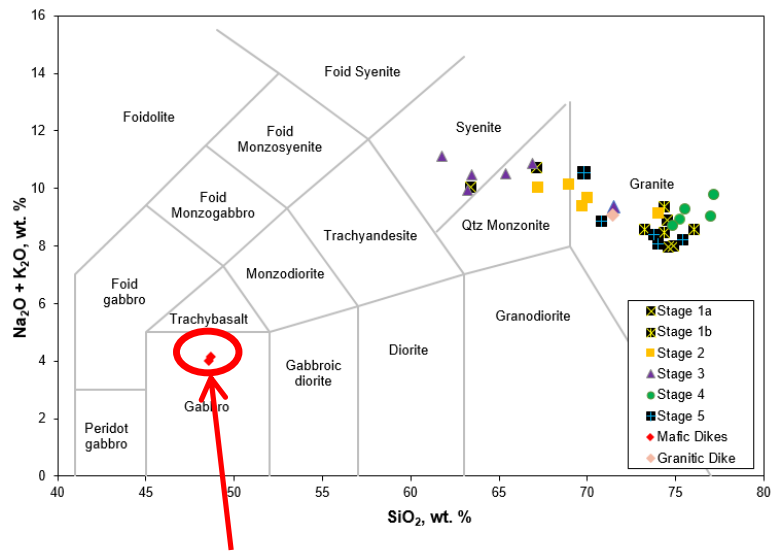

Diabase dikes

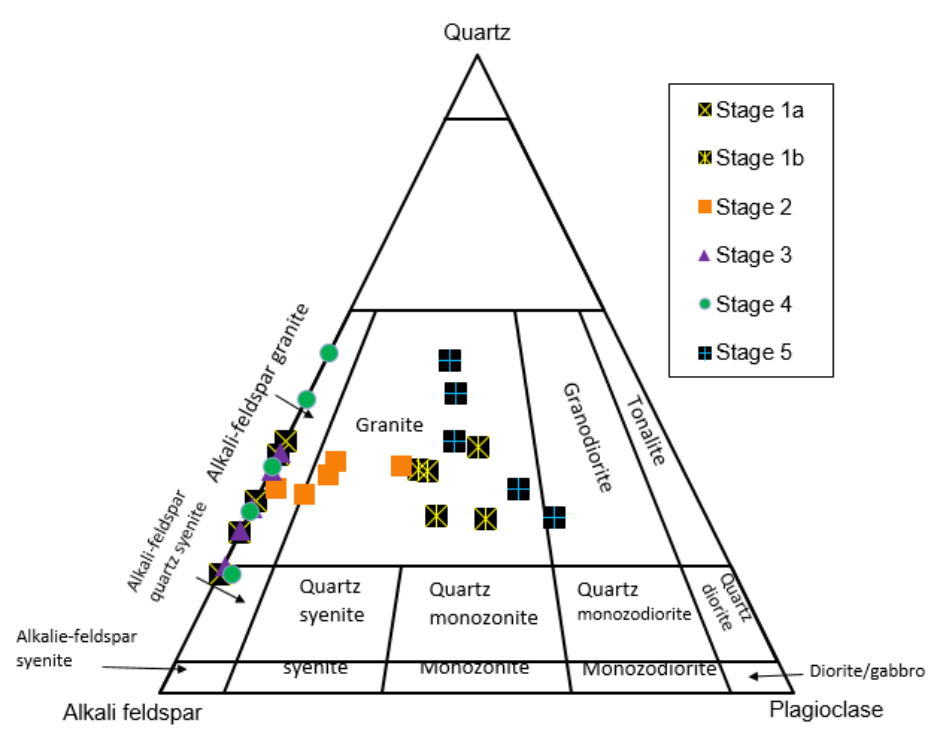

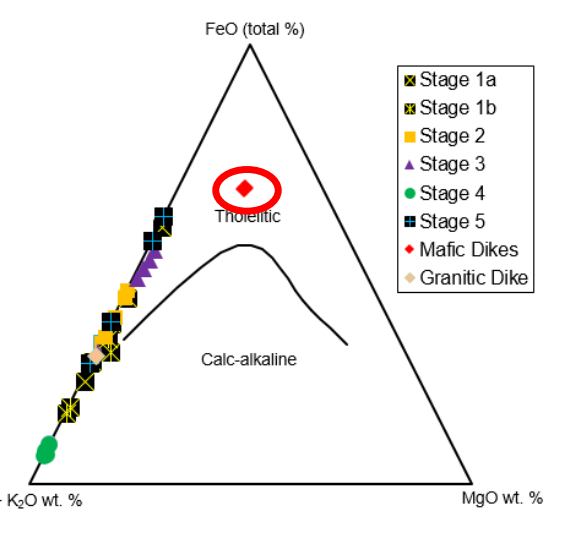
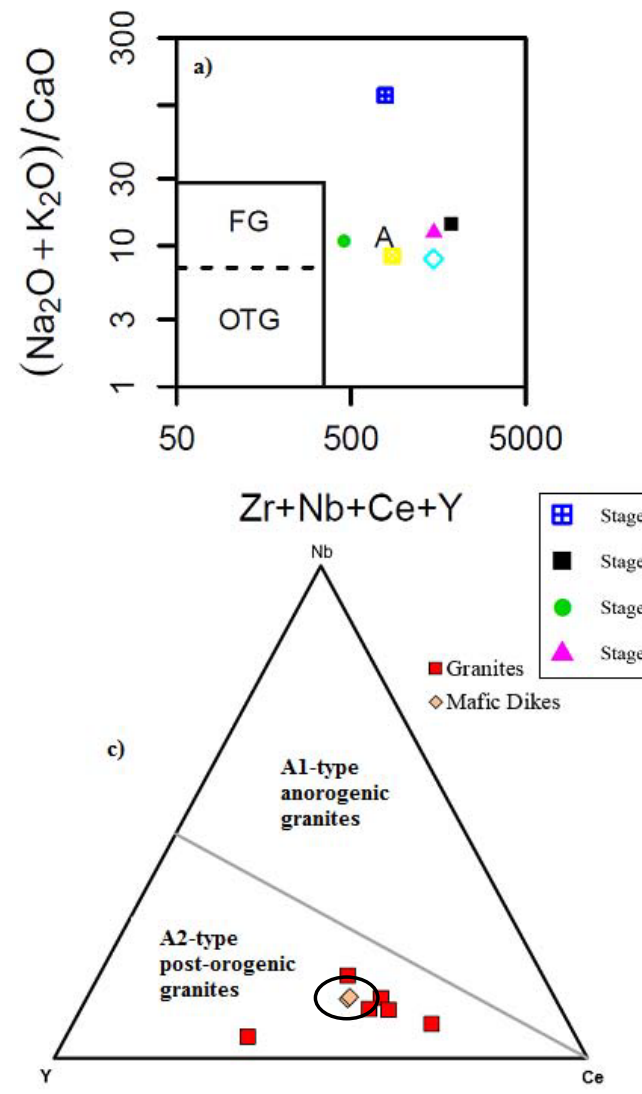
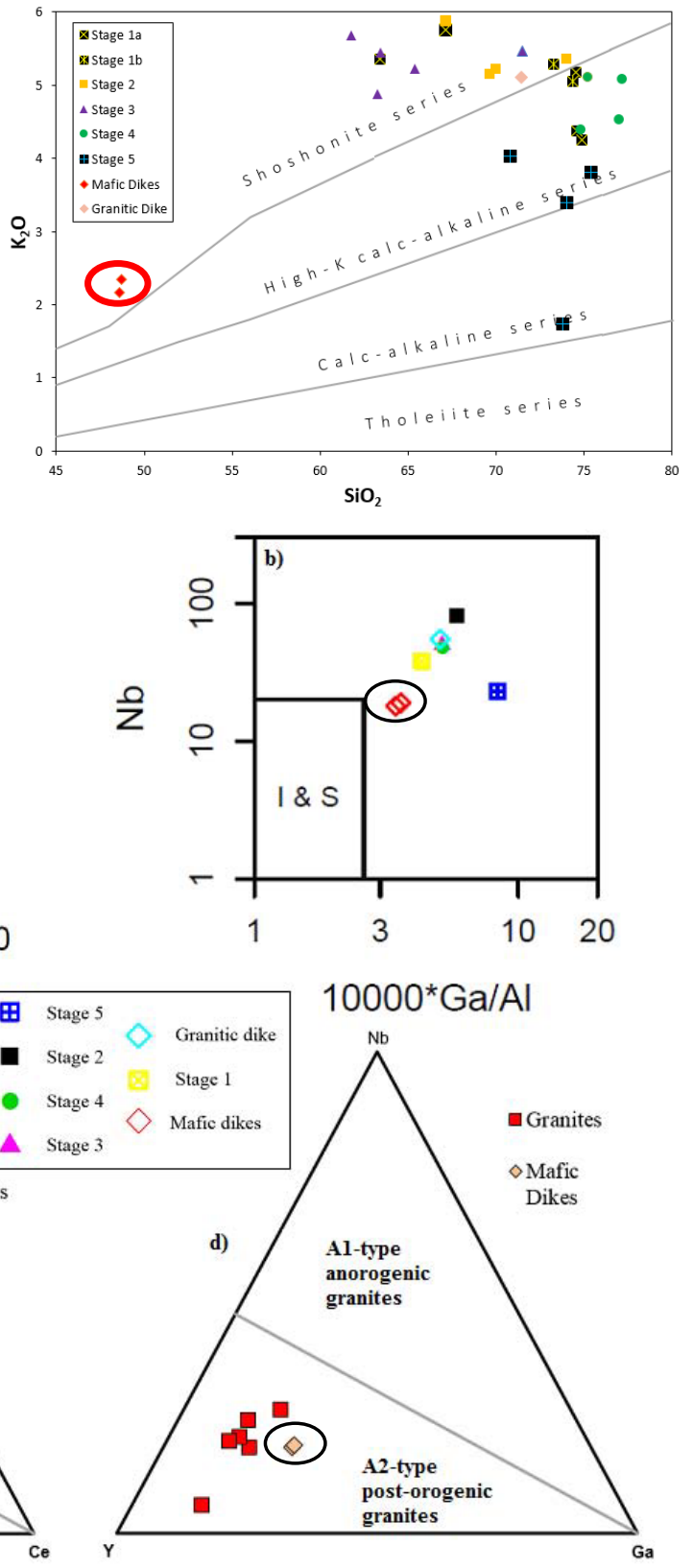


\section{Geochemistry of Red Bluff granite and mafic dikes}
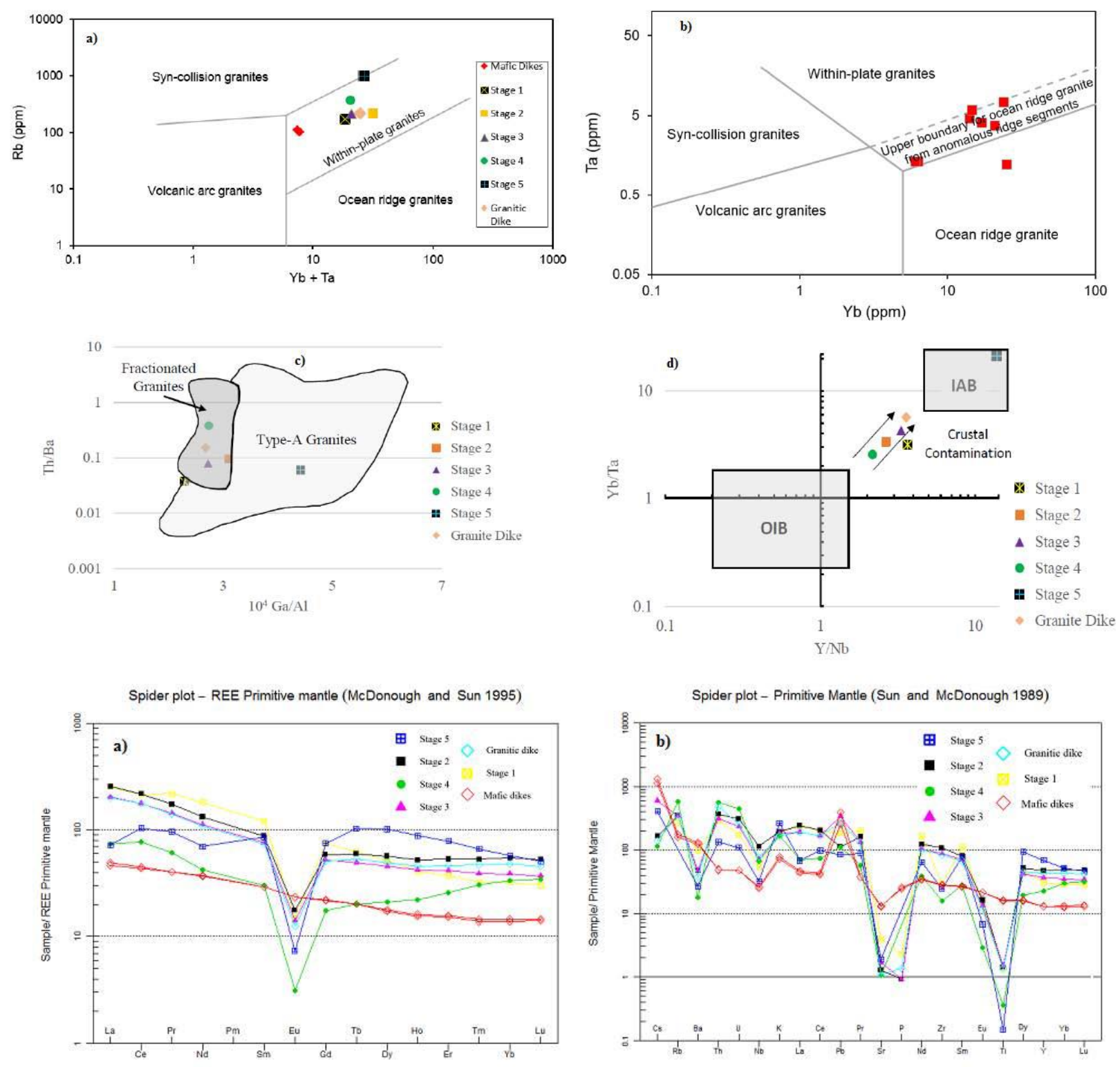


\section{Zircon U-Pb geochronology of granites and diabase dikes}
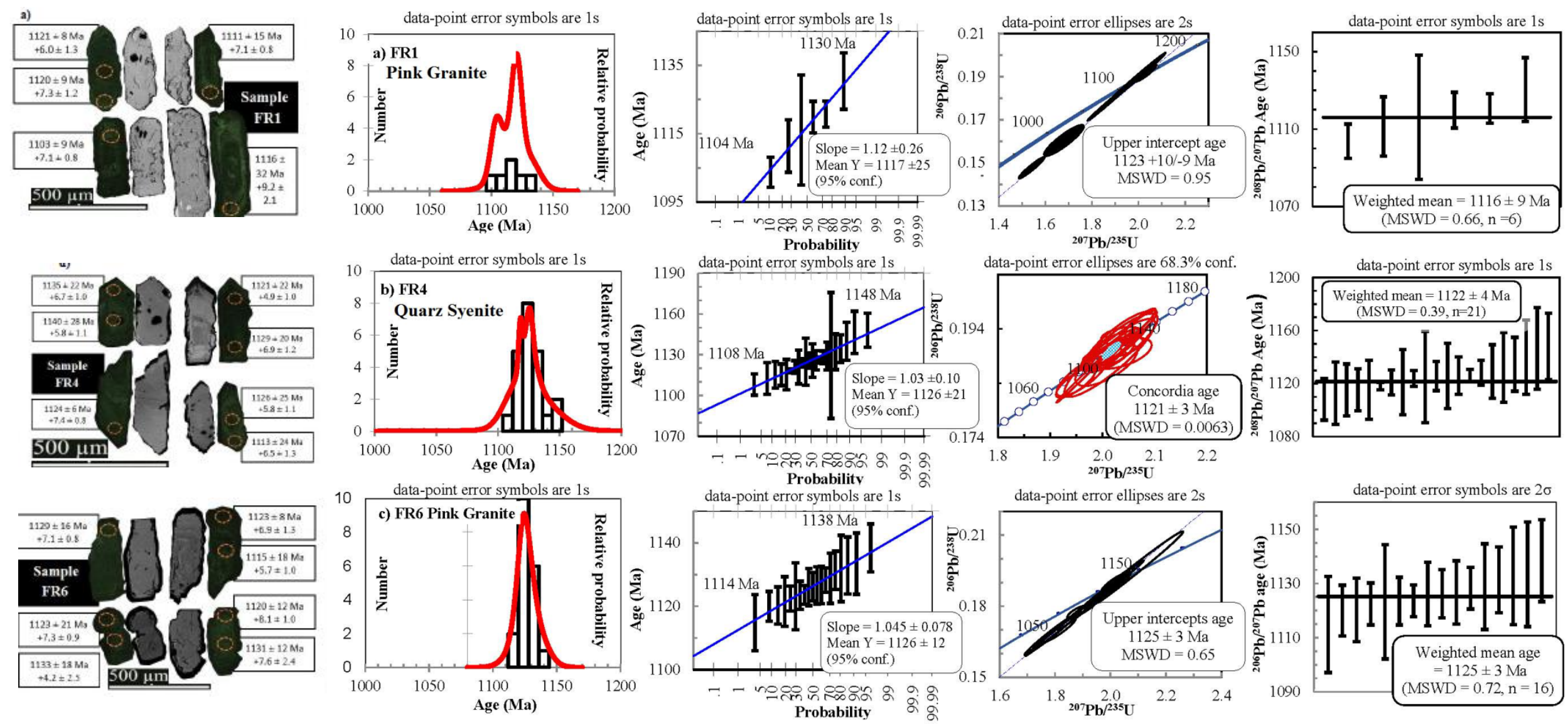

Oldest individual dates in granites $=========1176-1138 \mathrm{Ma}$ No inheritance from Paleo-Mesoproterozoic crust. 


\section{Zircon U-Pb Geochronology of granites and diabase dikes}
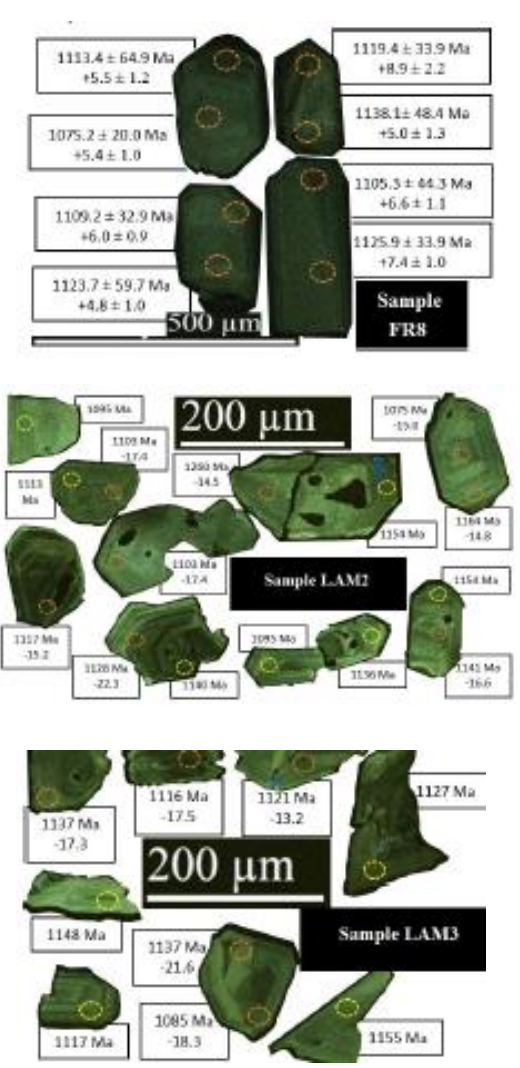
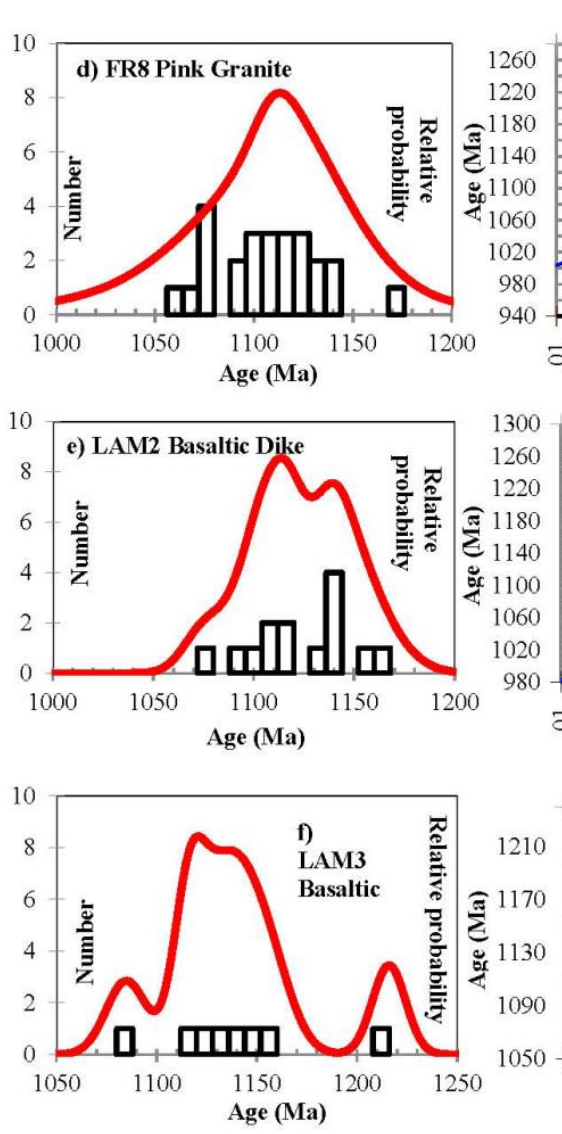

data-point error symbols are $1 \mathrm{~s}$
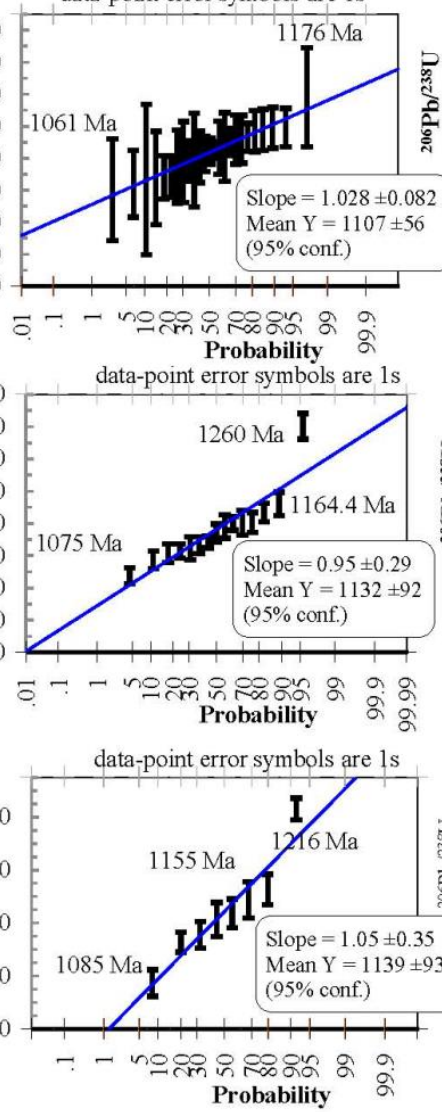
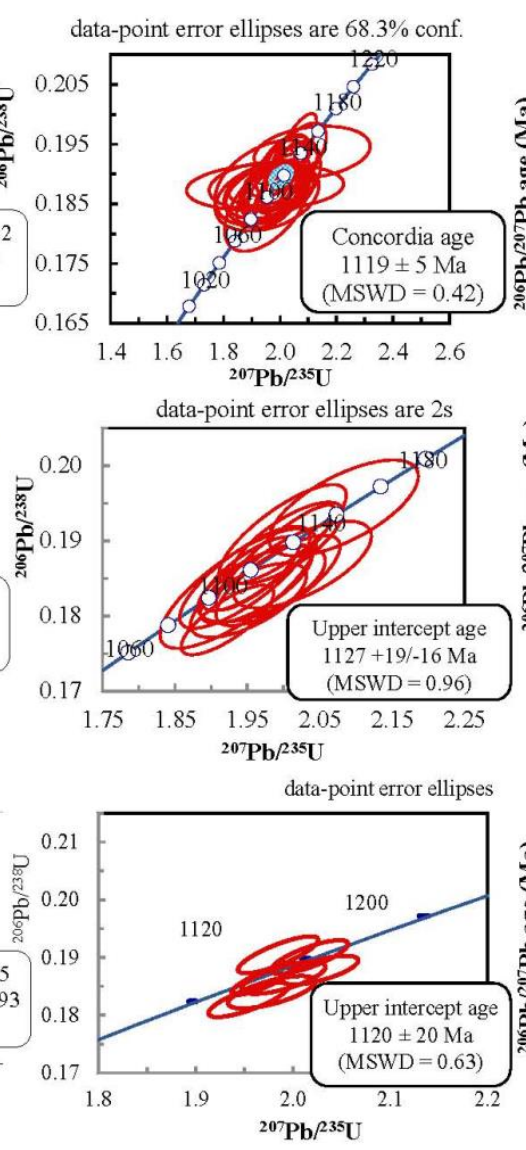

data-point error symbols are 1s

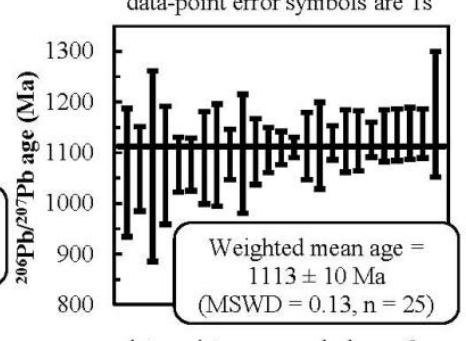

data-point error symbols are $2 \mathrm{~s}$

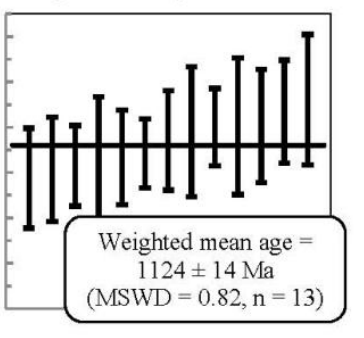

data-point error symbols are $2 \mathrm{~s}$

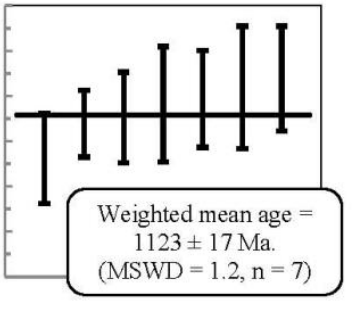

Oldest individual dates in diabase dikes $=========1260-1155 \mathrm{Ma}$ No inheritance from Paleo-Mesoproterozoic crust. 


\section{Zircon Hf isotopic evolution of West Texas and other 1.1 magmatic rocks in southwestern Laurentia}

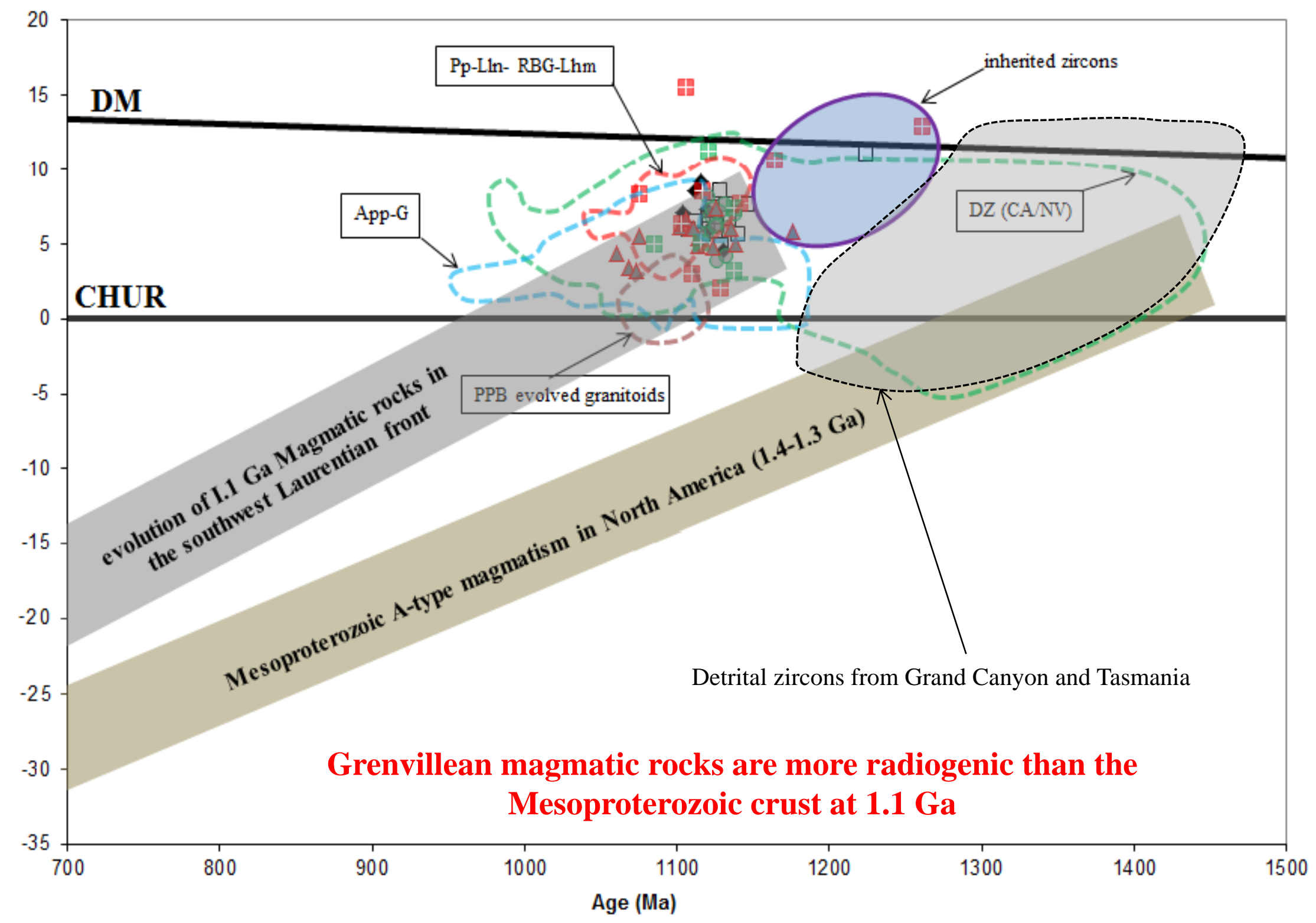




\section{Formation of Continent-Arc type Southwestern Laurentia}

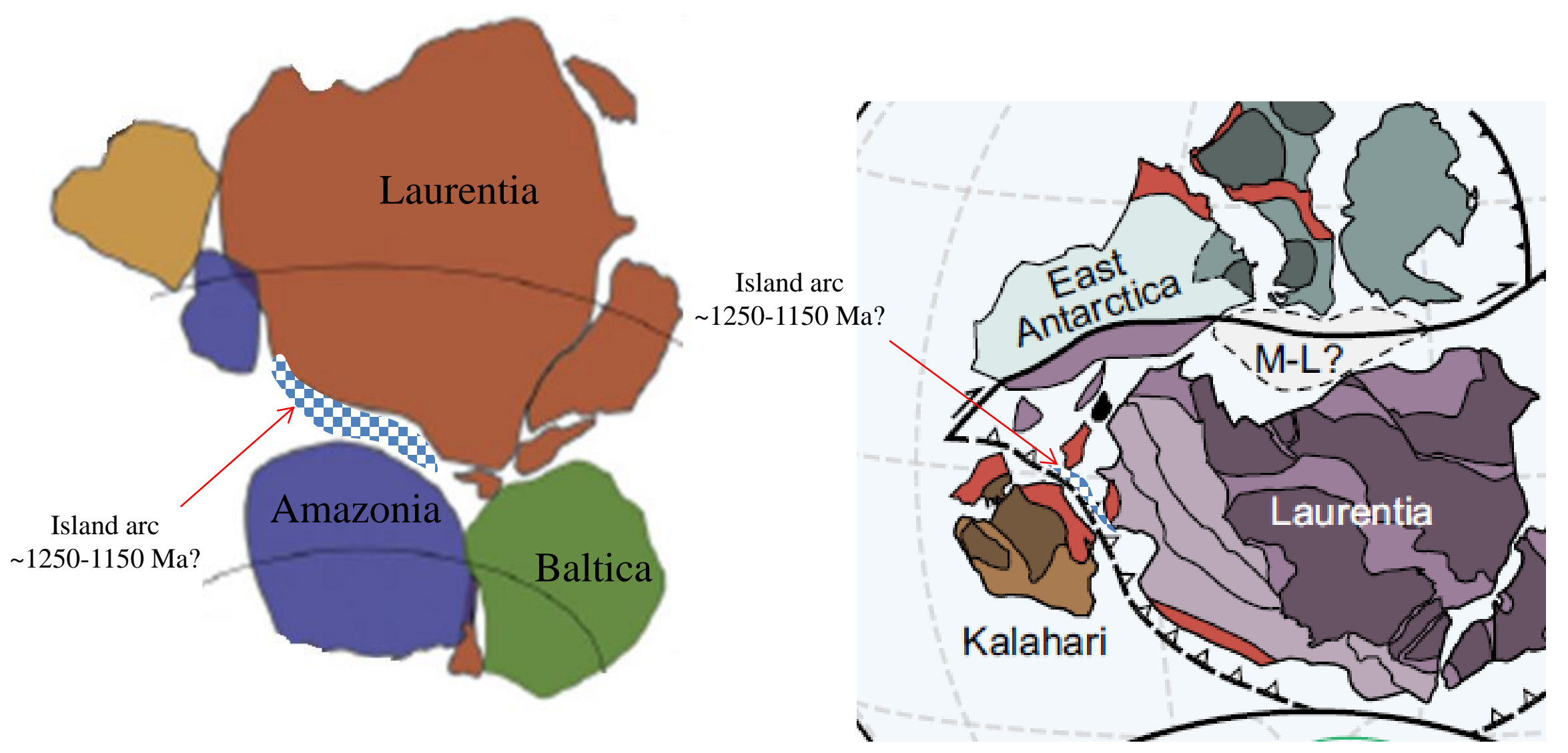




\section{Collision of Laurentia with a southern continent at $\sim 1200-1150 \mathrm{Ma}$}

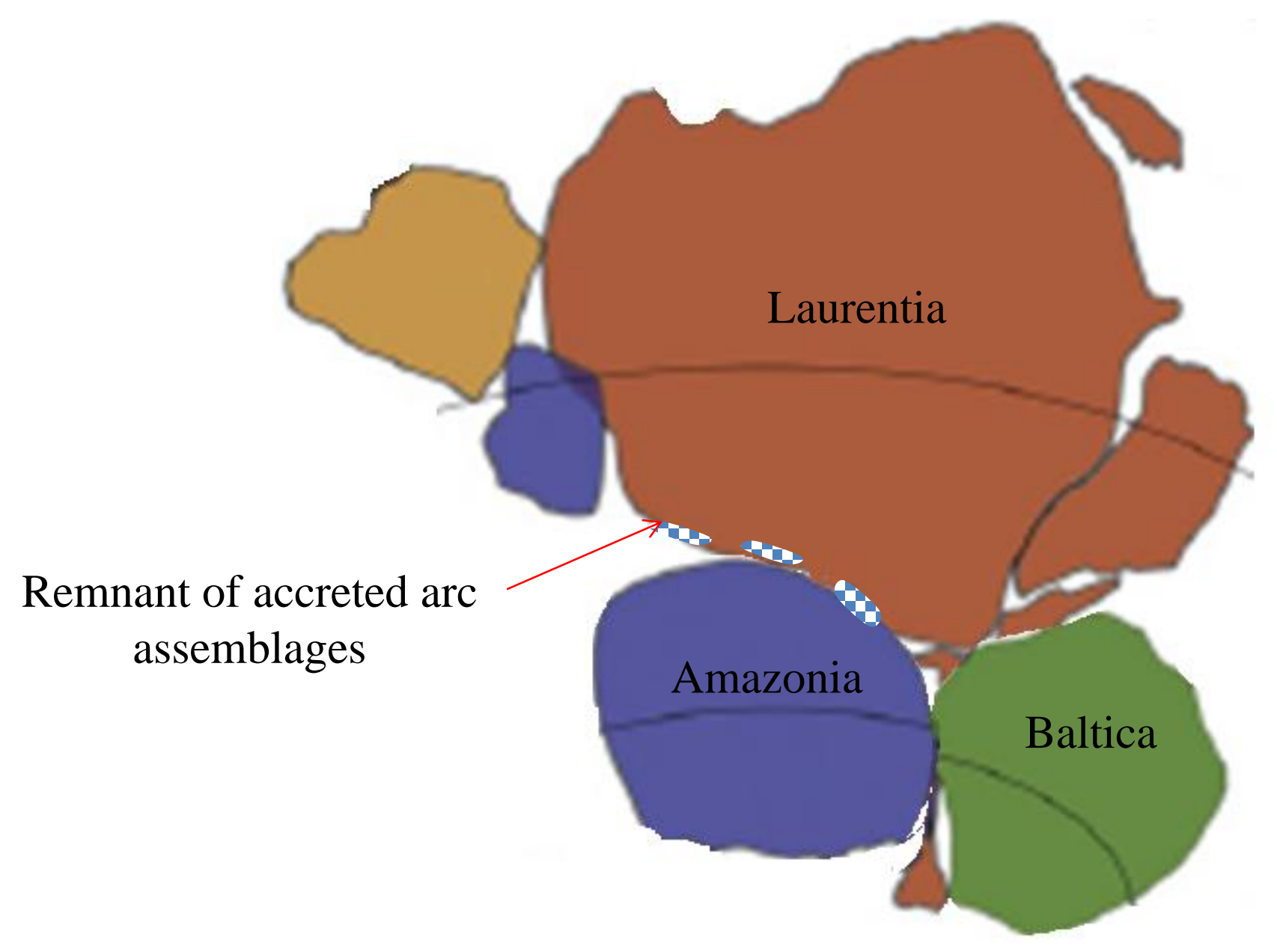




\section{Tectonomagmatic model for alkaline magmatism, deformation, leucogranites and migmatization in the west Texas and Llano $1.1 \mathrm{Ga}$}

s

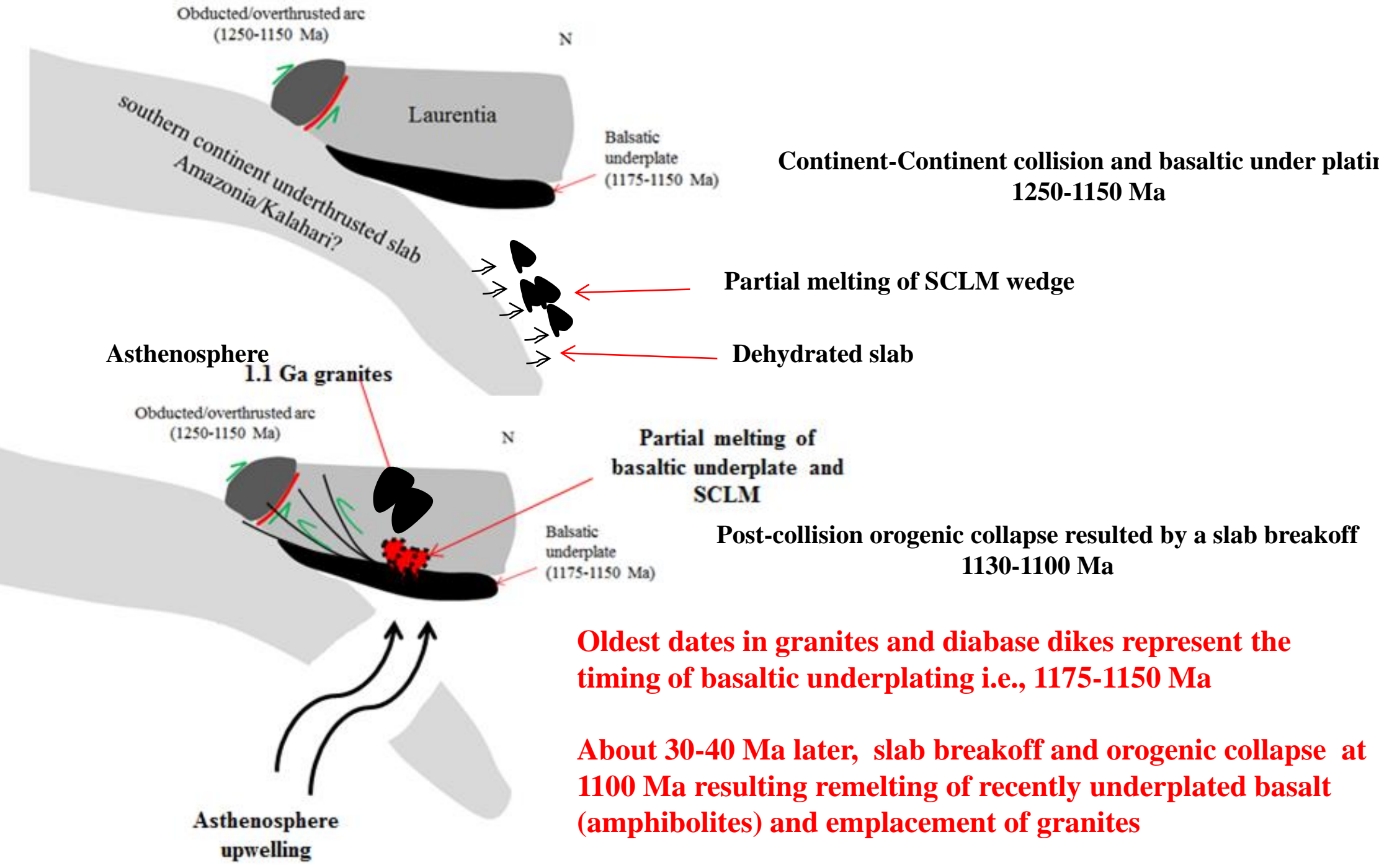




\section{Is Grenvillean orogeny an older analogue to the Himalayan collision zone}

Not a new idea though

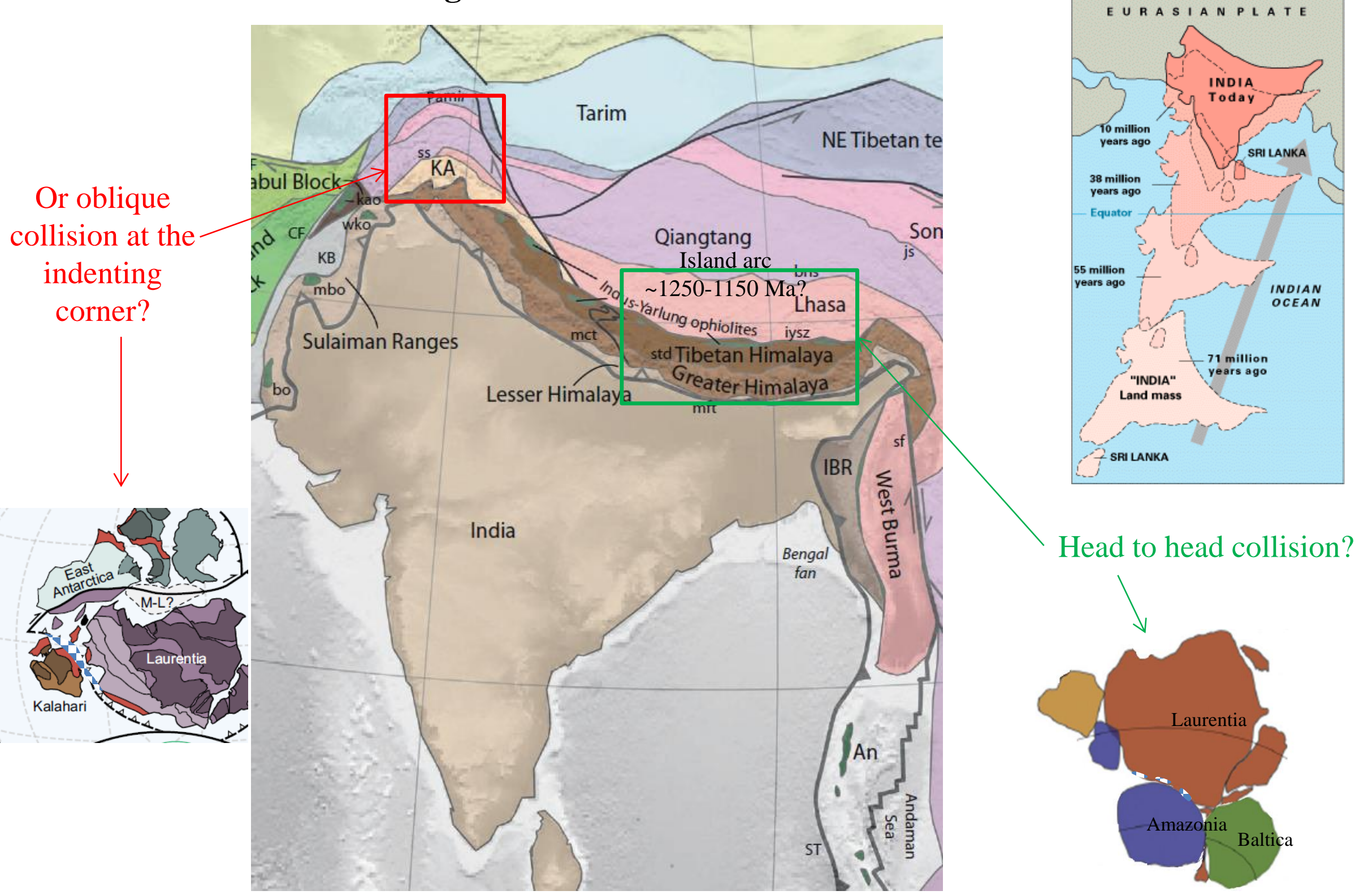




\section{South Eastern Grenville comparison to India-Asia head to head collision}

Collision of Amazonia and Southeast Laurentia

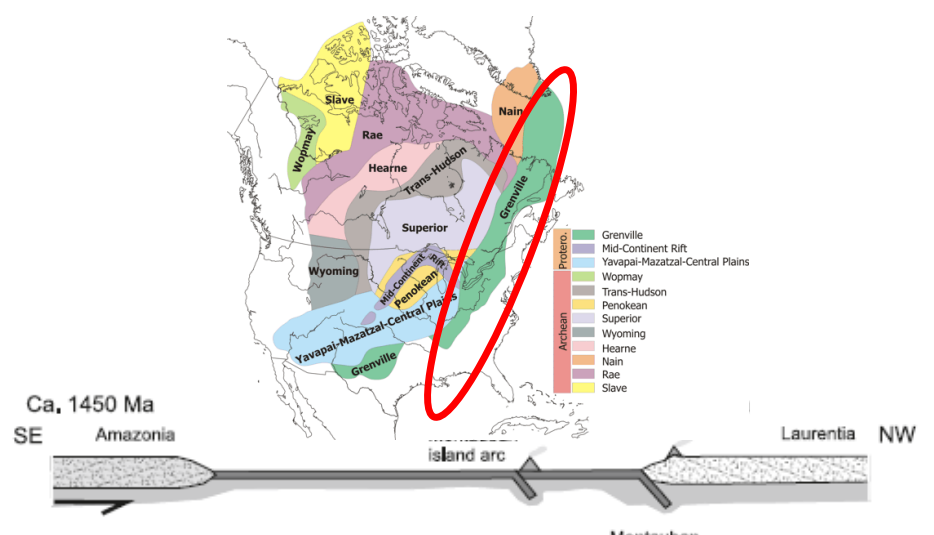

Ca. $1370 \mathrm{Ma}$

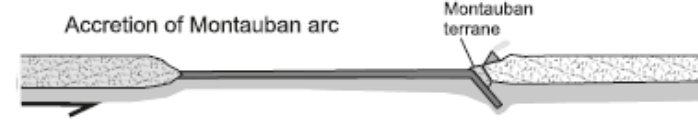

Ca. $1310 \mathrm{Ma}$

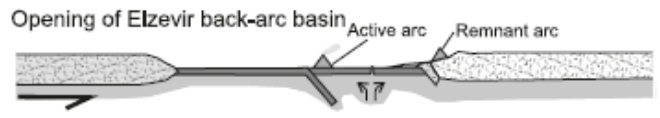

Ca. 1250-1220 Ma Closure of Elzevir marginal basin, initiation of SE-directed subduction
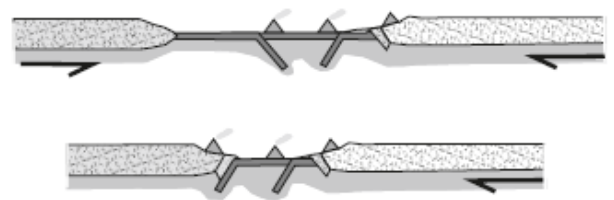

Ca. 1220-1180 Ma Accretion of Elzevir and Frontenac terranes (remnants of back-arc basins)

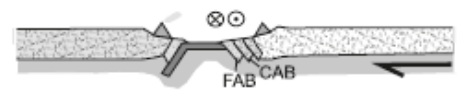

Ca. $1180-1120 \mathrm{Ma}$ Widespread crustal- and mantle-derived magmatism on Laurentian margin, limited extension

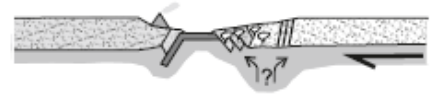

Ca. 1090-980 Grenvilian Orogeny: formation of ABT at ca. $1090 \mathrm{Ma}, \mathrm{ABT}$ reworked in extension at ca. $1020 \mathrm{Ma}$, formation of GF at ca. $1000 \mathrm{Ma}$

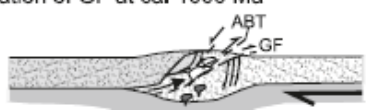

\section{Head to head India-Asia ollision}
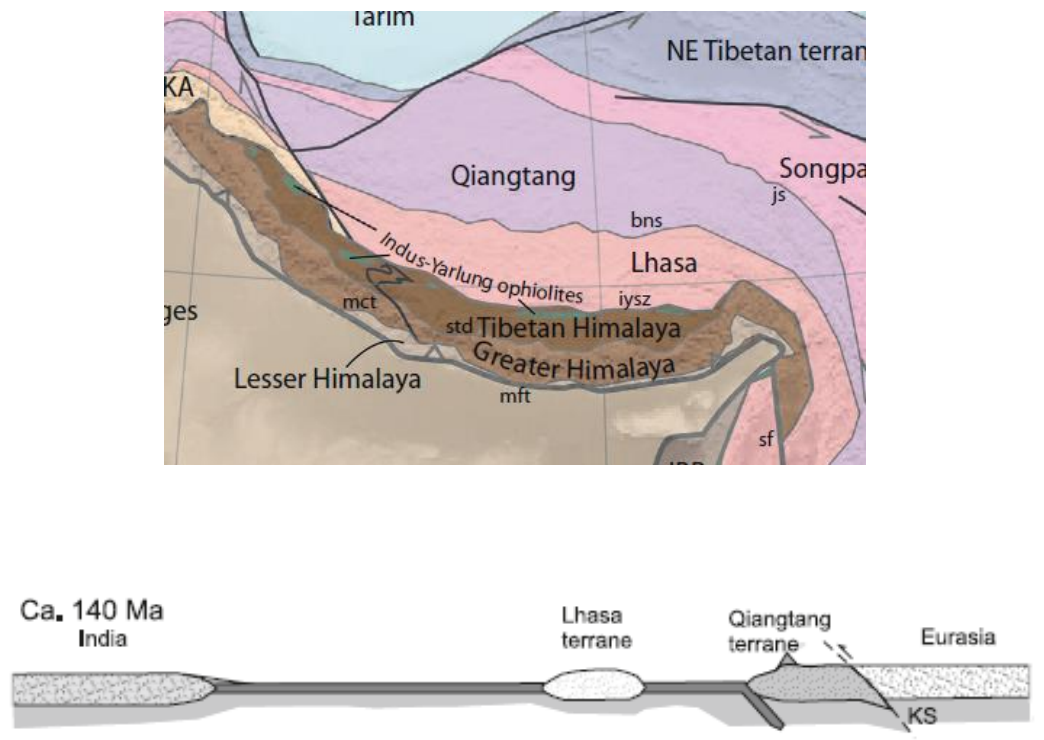

Ca. $100 \mathrm{Ma}$

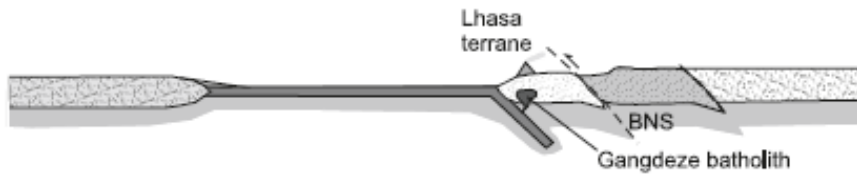

Ca. $55 \mathrm{Ma}$

Colision between India and

Eurasia; UHP metamorphism

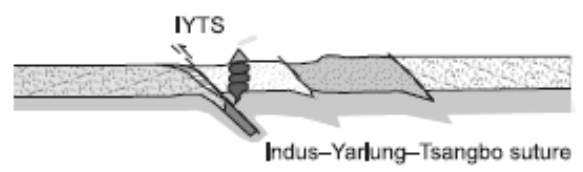

Ca. $23 \mathrm{Ma}$ - Present

Formation of MCT and STD and generation of leucogranite ca. $23 \mathrm{Ma}$ Formation of MBT ongoing

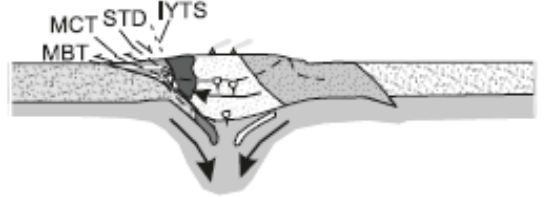




\section{India-Asia collision at northwestern indenting corner}

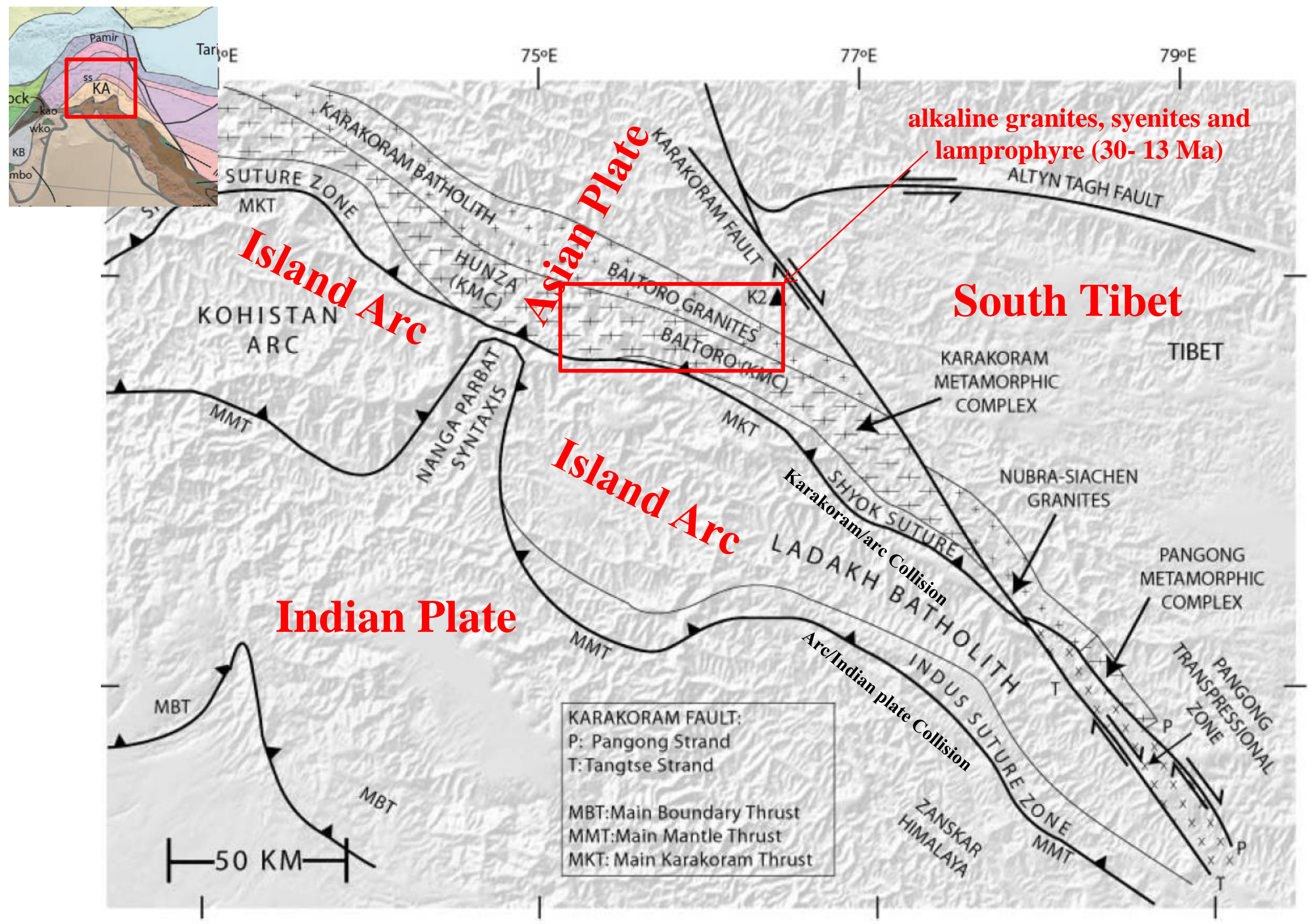




\section{Post orogenic slab break off and magmatism $\sim 30$ Ma following continent-continent collision}

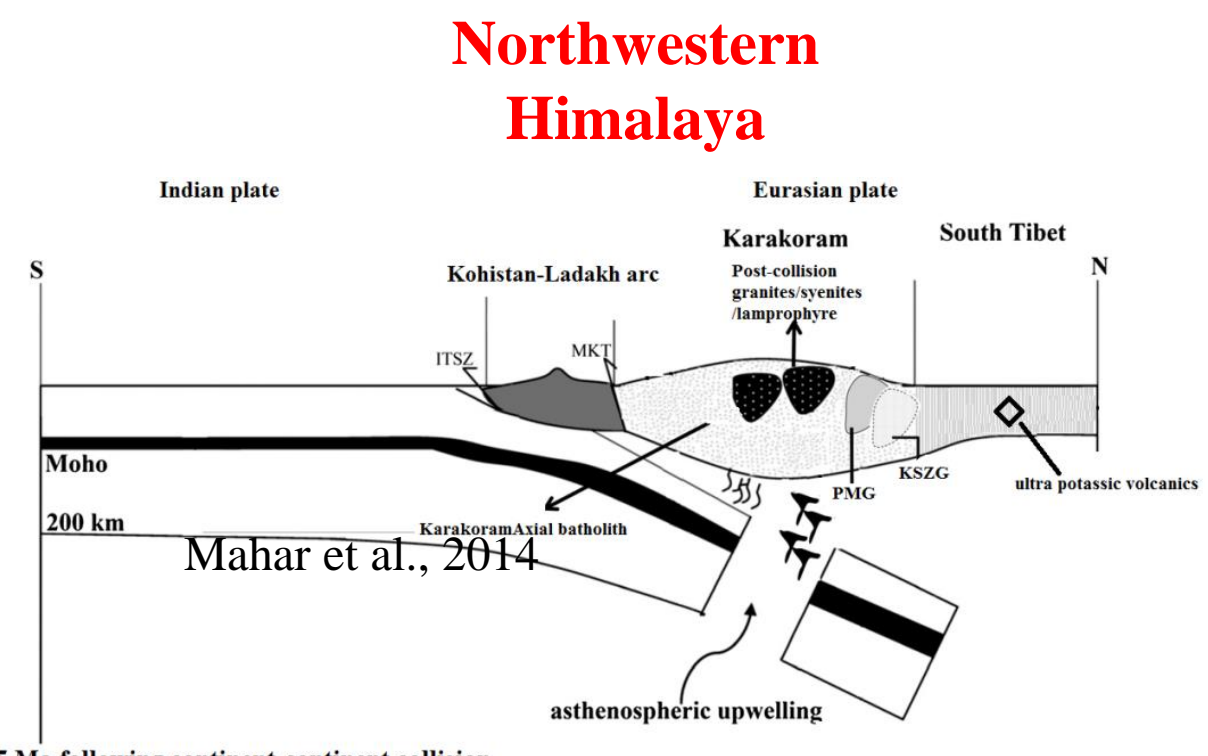

\section{Southwestern \\ Laurentia}

25 Ma following continent-continent collision

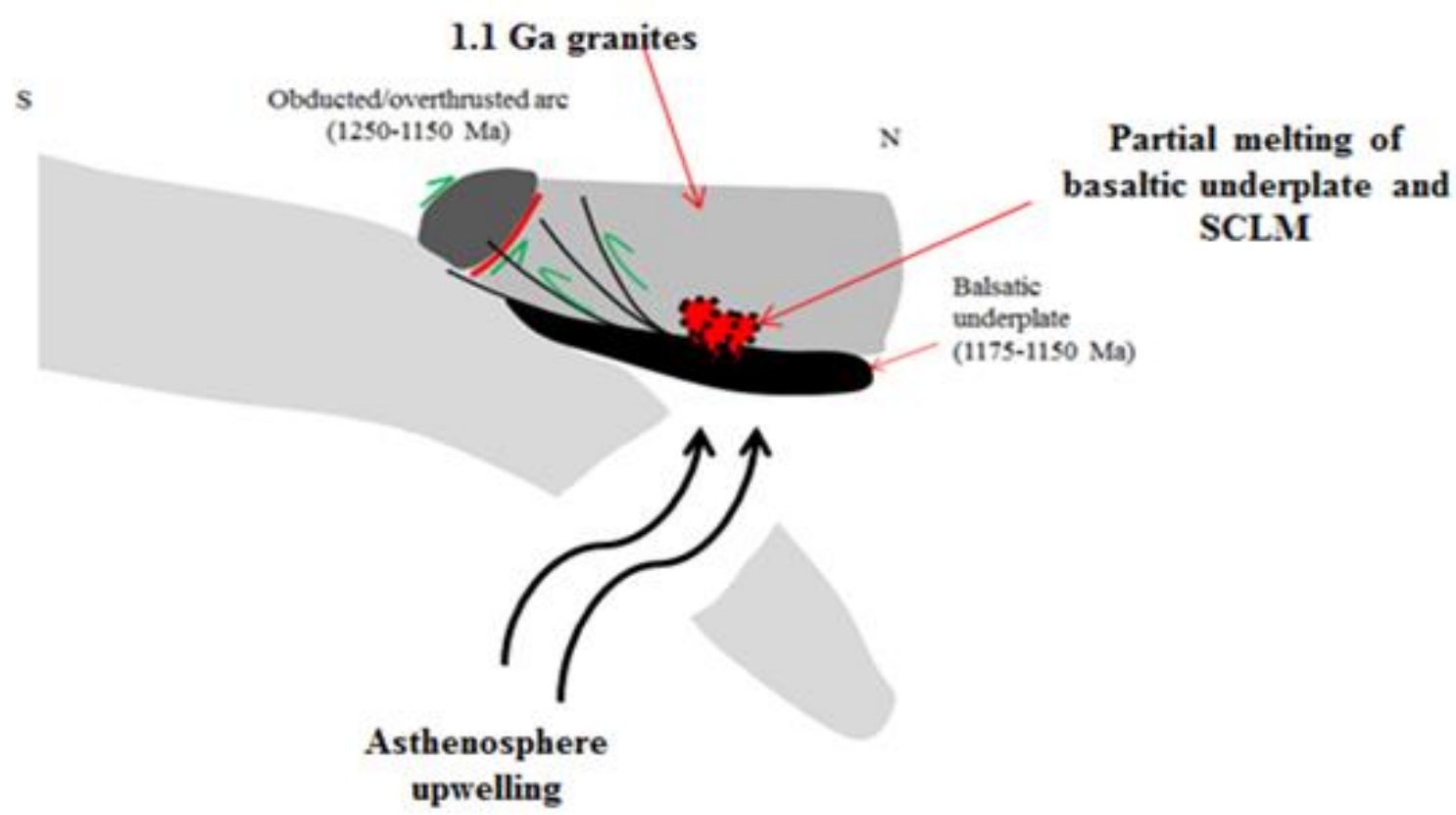

Southern most Laurentia is similar to the southern margin of Asian plate in northwestern Himalaya.

break off of descending slab under both plates.

Deformation, uplifting, and HT metamorphism

A sandwiched arc in both zones

Alkaline magmatism 30 Ma fllowing continentcontinent collision upwelling 


\section{Conclusion}

- Granites and associated basaltic dikes yielded overlapping ages ( 1.1 Ga) and Hf isotopes composition.

- Mafic dikes are possibly related to the basaltic underplate resulted by partial melting of SCLM which remelted by decompressing asthenosphere during a slab breakoff event.

- Absence of zircon inheritance and Hf isotope composition suggest minimal input from older Mesoproterozoic crust, perhaps southern margin of Laurentia is dominantly underlain by juvenile crust.

- For the origin of granites partial melting of basaltic under plate (amphibolites) is suggested.

- Southwestern Laurentia is similar to the southern margin of Asian plate in northwestern Himalaya both have recorded alkaline magmatism, migmatization, deformation and uplifting $\sim 30$ Ma following continent-continent collision. 